\title{
COMMUNICATIONS
}

\section{COATS'S DISEASE* \\ I. REVIEW OF THE LITERATURE, DIAGNOSTIC CRITERIA, CLINICAL FINDINGS, AND PLASMA LIPID STUDIES $\dagger$}

BY

\author{
ALAN C. WOODS AND JAMES R. DUKE \\ From the Wilmer Ophthalmological Institute of the Johns Hopkins Hospital and University, \\ Baltimore, Maryland
}

IN 1958 and in 1960, two adult patients who presented an unusual and almost identical fundus picture were seen in the Wilmer Institute. Both had recently developed retinal lesions which resembled heavy lipid deposits in the external retina and subretinal space with a consequent elevation of the retina itself - a picture indistinguishable from that of a conventional juvenile Coats's disease. Both had authenticated histories of repeated attacks of nongranulomatous uveitis.

The diagnostic survey of these two patients revealed periapical infections and a bacterial hypersensitivity which might have accounted for the repeated attacks of nongranulomatous uveitis. In addition, however, both had evidences of a disturbance in the systemic fat metabolism with a marked elevation of the total plasma lipids, especially involving the total cholesterol. These observations suggested that the stimulus of the repeated uveal inflammation in these two patients with a concomitant hypercholesteraemia might have initiated the deposition of lipids in the retina and subretinal space.

In the exploration of this idea, the somewhat confused literature on Coats's disease was first reviewed and analysed, especially for any information relative to lipid deposition in the eye or disturbance in the fat metabolism. Thereafter, all cases in the clinical and eye pathology files of the Wilmer Institute, in which a positive or suggested diagnosis of Coats's disease had been made, were sought for and restudied. As far as was possible, all patients in whom a final clinical or histological diagnosis of Coats's disease was justified, were recalled for further examination and determination of their blood lipids. The histological material from those patients in whom the histopathological diagnosis had been made, was restained and studied for the deposition and possible identification of any lipids in the retina and subretinal space. Finally, certain experiments were undertaken, exploring the possibility that a repeated or prolonged inflammatory insult might result in the deposition of lipids in the retina or subretinal space.

\footnotetext{
* This paper is divided into three parts. The first two were prepared by Dr. Alan C. Woods and Dr. James $R$. Duke. The experimental work for Part III was done by these two authors and the data were collected prior to the death of Alan Woods and a rough manuscript drawn up. A week before he died in Johns Hopkins Hospital, Woods told his more junior colleague that unfortunately the latter would have to complete the final manuscript alone.

+ Received for publication April 8, 1963 . 
The various phases of these studies will be reported independently. The purpose of the present communication is to present a summary of the pertinent literature, and the results of the clinical and blood lipid studies in these patients.

\section{Literature}

In 1908 Coats published his classical paper on a comparatively rare form of external retinopathy with massive exudation, in which he divided the condition into three groups. Since that date Groups I and II, as originally described by him, have borne his name and are conventionally known as "Coats's disease". Group III was somewhat different; in addition to the external retinopathy and massive exudation, it was characterized by large capillary angiomata in the retina with demonstrable arteriovenous communications. This condition had previously been described, was later recognized to be a different clinical entity, and is now known as the von Hippel-Lindau disease. This Group III is not concerned in the present discussion.

Groups I and II consisted of six cases personally studied both clinically and histologically by Coats himself, and of fourteen similar cases collected from the literature. In all these cases the clinical common denominator was the ophthalmoscopic picture of yellow or yellowish white masses of exudation in the external retina and beneath the retina, resulting in either a localized elevation or an actual retinal detachment. The retinal vessels coursed cleanly over these areas of exudation. Histologically, the common denominator was the presence of exudates in the external retina and exudates or an organized mass in the subretinal space. In the external retina and in the subretinal mass were many empty cells which were variously designated as "foam", "ghost", or "balloon" cells. There were also empty spaces which are usually called "cholesterol clefts". On the basis of the presence or absence of obvious haemorrhage or vascular changes, Coats divided his cases and the fourteen collected from the literature into two groups.

Group I consisted of two cases personally examined and studied by Coats and seven cases collected from the literature. In addition, Coats collected from the literature fifteen or sixteen somewhat similar cases which had been examined clinically, but in which no histological reports were available, and in which there were insufficient data to permit any analysis.

All the nine cases in this group were unilateral; two were adult males and one an adult female, and the six juvenile cases, 19 years or less of age, included five males and one infant female. In none of these cases was there any significant clinical or histological evidence of haemorrhage or vascular changes. The choroid was usually atrophic, was often adherent to the underlying retina, and at those points there was a mononuclear cellular infiltration. In Coats's two personal cases and in four of the seven cases collected from the literature, histological examination of the sections revealed cholesterol clefts and what were presumed to be cholesterol crystals.

Group II consisted of four cases examined by Coats, and seven collected from the literature in whom histological examinations had been made. The disease was again unilateral in all. Five of the eleven patients were adults (three males and two females) and six were infants or juveniles (five males and one female). In this 
group, in addition to the external and subretinal exudation, there were marked vascular changes. These consisted of numerous fresh haemorrhages, and changes in the smaller retinal arterioles which he described as "irregularities of calibre, fusiform and beaded..." with "loops, kinks, and small spiral tortuosities, brushes and glomeruli...". The choroid was usually atrophic and as a rule showed little or no evidence of any present or preceding inflammation. In three of Coats's personal cases, and in three from the literature, there was specific mention of the presence of cholesterol clefts, and of probable cholesterol crystals in the sections.

In the consideration of possible aetiological factors, Coats discussed syphilis, tuberculosis, and bacterial metastasis, but discarded these as highly improbable causes. Acting on the premise that "with the exception of the lens, the presence of cholesterin crystals in a tissue is almost to be regarded as diagnostic of a preceding haemorrhage", Coats came to the conclusion that the organization of haemorrhage was probably the true explanation for the subretinal mass. He admitted, however, that the haemorrhage might well be secondary to some infectious process. This same view he maintained in a later paper (Coats, 1912) in which he reported four additional cases.

Coats's clear and convincing paper at that time established his Groups I and II as recognized clinical and histological entities. Since this time, however, there have been numerous additions and embellishments, and other aetiologies have been suggested. In his classical textbook, Duke-Elder (1940) lists six conditions which have the common denominator of external and subretinal exudation. Several of these are probably identical, but many ophthalmologists regard them, and still other more remotely allied conditions, as variants of Coats's disease. The result has been that this syndrome, originally so well described by a master ophthalmologist, has become increasingly ill-defined.

As concerns the aetiology of Coats's disease and the deposition of lipids in the retina and subretinal space, the questions discussed in the voluminous, repetitive, and often confused literature may be summarized as follows:

1. Are the external retinopathy and the subretinal exudation and fibrosis of Coats's disease the result of a local inflammatory reaction or of a preceding haemorrhage?

2. What is the role and the pathogenesis of the telangiectasis and other vascular changes which are so often such a prominent feature?

3. What is the origin and role of the foam cells in the pathogenesis of the disease?

4. Is Coats's disease an individual disease entity or is it only a variant of the large group of retinopathies which are characterized by the local deposition of lipids?

5. What is the relation, if any, of Coats's disease to a disturbance of the systemic fat metabolism?

6. What factors initiate and facilitate the deposition of the lipids in Coats's disease?

(1) Is Coats's disease a local inflammatory reaction or is it the result of a preceding haemorrhage?

The first of the early advocates of an inflammatory aetiology were von Hippel (1913) and Leber (1916). Von Hippel reported a case of Coats's disease which showed histologically a marked chorio-retinitis and he believed that any haemorrhage was secondary. Leber, writing in the Graefe-Saemisch "Handbuch", 
discussed at length the clinical symptomatology, histology, and probable pathogenesis of Coats's disease. He took definite exception to Coats's premise that the presence of cholesterol crystals or clefts were pathognomonic of preceding haemorrhage. He pointed out that, while the red blood cells did contain cholesterol, the probable source of cholesterol deposits in the tissues was the blood plasma. $\mathrm{He}$ believed the condition to be primarily an inflammatory reaction and advanced the following theory for the pathogenesis of Coats' disease:

Under the stimulus of an inflammatory process which primarily affected the retina, but might also involve the choroid, there ensued a proliferation of the pigment epithelial cells, which then either synthesized cholesterol or more probably phagocytosed it from the serous exudate and necrotic retinal tissue which they had infiltrated. These cells finally gave rise to fibroblasts which encapsulated the subretinal mass.

Among the other investigators who reported cases supporting this hypothesis of an inflammatory aetiology were Hanssen (1920) and Meller (1922); 30-odd years later it was more specifically suggested that toxoplasmosis might be related to the pathogenesis of the disease (see below).

This idea of an inflammatory aetiology for Coats's disease was quickly challenged. Berg (1919) reported four cases in which the vascular changes were a prominent feature. He described the vascular changes as perivascular lymphocytic infiltration, proliferation of the capillary endothelium, partial or complete vascular thrombosis, and the formation of miliary aneurysms, all of which lead to exudation and haemorrhage into and beneath the external retina. These vascular changes were followed by proliferation of the pigment epithelium. He believed the vascular changes to be the actual cause of the subretinal exudation. He quoted a number of earlier reports by other authors who had observed similar changes in various conditions, and he believed these were all probable cases of Coats's disease. He noted the similarity of the histological pictures of Coats's and Lindau's diseases and expressed the view that these were related entities. Similar views were expressed by Crigler (1920), Miyashita and Nisyaka (1921), Rados (1921), H. Friedenwald (1925) and Mylius (1935). Gourfein-Welt (1920) emphasized the fact that many cases of typical Coats's disease showed telangiectases of the retinal vessels. Junius (1934) pointed out that Coats's disease frequently occurred in patients with a generalized telangiectasis and that the probable cause of the systemic and retinal vascular changes were minute physico-chemical changes in the walls of the small arterioles. Klein (1937), reporting the histological examination of a case of Coats's disease, noted psammoma-bodies throughout the retina which she believed to be the result of hyalinization of the vascular loops and aneurysms. Elwyn (1946) regretted that Leber had suggested that inflammation or degenerative changes were the actual precipitating cause of Coats's disease. He visualized the pathogenesis as a primary outpouring of plasma into the retina, haemorrhage, necrosis of the retinal elements, invasion of the retina by phagocytic cells derived from the pigment epithelium, and finally the organization and encapsulation of haemorrhage too large to be absorbed. He differentiated Coats's disease from the condition described by von Hippel and Lindau. In his description of the pathology he noted the fine network of reticulin, the formation of new capillaries lined with flat endothelial cells, the ability of these cells to take up lipids from destroyed nerve tissue, and their resultant resemblance to xanthoma cells. Givner (1954) also 
reported a case which supported the hypothesis that the disease was of vascular aetiology. Vascular changes were present in seven of the eight juvenile cases reported by Imre (1962). Imre apparently inclined to the view that these vascular changes were related to the aetiology of the disease, quite possibly through some endocrine imbalance.

Other investigators likewise appear to believe that the telangiectases of the external retina are per se the actual cause of the external retinopathy of Coats's disease. In his Gifford Lecture, Reese (1956) defined telangiectasis retinae as small miliary aneurysms which appeared as circumscribed globular retinal lesions with small, sharply outlined borders. He specifically noted that, in addition to Coats's disease, such vascular lesions might occur in diabetes, venous occlusion, and other pathological conditions. However, in these conditions, the telangiectases lay in the internal retina, and any secondary haemorrhage would occur there or in the vitreous. He reported two juvenile cases of telangiectasis retinae which he had observed progressing from the early stage of telangiectases to the typical clinical and histological picture of Coats's disease. In the telangiectases of these patients he demonstrated a polysaccharide subintimal membrane which stained vividly with the periodic acid-Schiff stain, and he suggested that this material might be the tissue-factor which led to atresia and occlusion of the capillaries, with subsequent haemorrhage, oedema, and deposition of crystals in the retina, and ultimately to the final organization of the subretinal mass. Reese urged that the term "Coats's" disease should be limited to this class of case, and not applied to other unrelated conditions.

Since Reese's paper, the reports of Fracassi (1956), Valvo (1956), Sugar (1958), and Bauer (1959) have endorsed the now widely held view that telangiectasis retinae is the actual cause of the external exudative retinopathy of Coats.

(2) What is the pathogenesis of the telangiectasis and other vascular changes which are such a salient feature of Coats's disease?

Lindau (1926) pointed out that the capillary aneurysms characteristic of von Hippel's disease often, if not constantly, occurred in association with similar capillary aneurysms in the cerebrum. He believed the actual cause of these vascular changes might be either a congenital anomaly or some metabolic disturbance.

As already noted, Junius (1934) had suggested that the probable cause of these telangiectases was a series of minute physico-chemical changes in the walls of the small arterioles.

Wise $(1957,1961)$ advanced a most interesting hypothesis of the pathogenesis of these vascular changes, which may be quite pertinent in Coats's disease. He discarded completely the generally accepted belief that the vascular changes and resultant haemorrhages were primary. He believed that, irrespective of whether retinal telangiectasis occurred in the internal or external layers of the retina or not, they were in their essence the response to a metabolic cellular need-a local hypoxia of the tissues.

In his first paper he recalled the "dormant embryological mechanism" described by Michaelson (1954), which assumed that embryonic development of the retinal vessels was the result of a response by some tissue factor present in the areas of retinal hypoxia. As the surrounding capillaries developed, and these areas received sufficient oxygen, this factor would be inhibited and further capillary development 
therefore limited. This vasoformative factor does not disappear, but remains dormant in the tissues and, should hypoxia recur, neovascularization would ensue. In the normal retina the outer layers receive oxygen partially from the vascularized inner retina, but chiefly from the underlying choriocapillaris. Wise explains the neovascularization which occurs in Coats's Group II cases, and the outward growth of the newly-formed capillaries, on the grounds that some impairment of the retinal circulation, chiefly on the venous side, together with the separation of the outer retina from the underlying choriocapillaris, results in a hypoxia of the outer retina. This hypoxia causes a reawakening of the dormant vasoformative factor, with consequent neovascularization, and the formation of capillary aneurysms. Wise recognized that organization of preceding haemorrhage is the conventionally accepted mechanism for subretinal fibrovascular tissue in Coats's disease, but disagrees sharply with the view that the haemorrhages are per se the primary change. He believes that any haemorrhage, whether it be a vitreous haemorrhage such as may occur in diabetic retinopathy, or the subretinal haemorrhage which may occur in some cases of Coats's disease, is a secondary manifestation resulting from the rupture of newly-formed, delicate blood vessels. In his second paper (Wise, 1961), he presents histological evidence which strongly supports this hypothesis.

(3) What is the origin and role of the foam cells in the pathogenesis of Coats's disease?

When Leber (1916) expressed the opinion that the foam cells arose from a proliferation of the pigment epithelial cells, he was apparently unaware of the previous work of Anitschkow $(1913,1914)$ in Aschoff's laboratory. This earlier investigator had clearly demonstrated that the foam cells found in xanthomatosis were histiocytes derived from the reticuloendothelial system. While Leber was among the first to recognize the importance of the foam cells and their relation to the phagocytosis of lipids, his probable mistake as to their origin and subsequent metamorphosis into fibroblasts was perpetuated in the literature for many years. However, Heath (1932) recognized this error when he classified Coats's disease under the generic term "ocular lipid histiocytoses". Marshall and Michaelson (1933), by histological examination of typical cases of juvenile Coats's disease, conclusively showed that the pigment epithelium was not the origin of the foam cells. The eyes examined by them showed marked changes in the retina, but the pigment epithelium and the choroid were entirely normal. They believed the foam cells were originally histiocytes from the reticuloendothelial system. They were aware that Castello (1927) had demonstrated that there were no histiocytes in the normal retina and therefore cited the earlier work of Oguchi and Majima (1923), who had shown that histiocytes were mobilized in great number in the retina as a result of inflammation. It is a fair statement that since the publication of Marshall and Michaelson's paper it has been generally accepted that the foam cells were originally histiocytes engaged in their routine business of phagocytosis.

\section{(4) Is Coats's disease a variant of other lipid retinopathies?}

Heath (1932) classified Coats's disease, Niemann-Pick disease, arteriosclerotic retinopathy, von Hippel-Lindau disease, and disciform (Junius-Kuhnt) degeneration of the macula under the generic term of "ocular lipid histiocytoses." Duke- 
Elder (1941) followed much the same idea, classifying conditions which all had the common denominator of exudation between the retina and choroid in the same group. Sugar (1958) recently reported eleven cases under the generic name of Coats's disease. On scrutiny, however, only three of these appeared to have the subretinal mass or exudation which is the salient characteristic described by Coats. The others were apparently cases of von Hippel-Lindau disease, diabetic retinopathy, and Junius-Kuhnt and the ordinary senile macular degeneration. These cases all had the common denominator of telangiectasis retinae. Sugar conceived the basic process to be a leak from the vascular lesions, the exudate in some cases arising from the blood plasma and in others from degenerated tissue elements. This material was phagocytosed by histiocytes. In some instances, the resulting clinical picture might be a circinate retinopathy, while in other cases, where the hemorrhage and exudate were larger, it resembled the more massive lesions seen in the typical Coats's disease. Various other reporters have followed this same conception of Coats's disease. This has reached such a point that Reese (1956) uses the term "waste-basket" to describe such classifications.

There is considerable evidence indicating that lipids other than cholesterol are those concerned in the retinopathies which may complicate other systemic lipidoses. Thus, in Niemann-Pick disease, a retinopathy quite different clinically from that of Coats's disease is a frequent complication. In this disease the lipid in the atypical foam cells of the systemic lesions has been identified as the diaminophosphatide sphingomyelin (Thannhauser, 1958). In idiopathic hyperlipaemia the usual retinal change is lipaemia retinalis (Dunphy, 1950), in which there are no actual exudates and in which the peculiar colour of the retina is due to the high concentration of chylomicrons and neutral fats in the blood serum. However, a retinopathy characterized by oedema, haemorrhage, and hard yellowish deposits in the internal retina was reported by Thomas and Smith (1958) in a patient with idiopathic hyperlipaemia. In this case the nature of the lipid deposits was not identified. However, in a quite similar case reported by Blodi (1960), histological examination showed several changes suggestive of Coats's disease, but there was no subretinal exudation. Blodi employed differential fat stains in an effort to identify the actual nature of the lipid deposits, and came to the conclusion that the lipid responsible for the retinal deposits was a neutral fat.

There was also considerable investigation on the fat transport in patients with diabetic retinopathy. Wolter, Goldsmith, and Phillips (1957) reported on the histological examination of eyes from patients with diabetic retinopathy. These eyes showed degeneration of the neural elements of the retina, vascular changes, hyalinization, and fibrosis of the arterioles with partial or complete obstruction of the lumina. There were masses of fat-laden phagocytes, but the nature of the lipid was not determined. The various investigations on the role of a hyperlipaemia in the fat transport in patients with diabetic retinopathy were summarized by Adlersberg and Eisler (1958), and by Finley (1960). It was shown that, in diabetic patients with retinopathy, but without renal involvement, the basic disturbance in the fat metabolism was a marked elevation in the triglycerides of the blood plasma. It has previously been shown (Korn, 1955) that, in addition to its action in decreasing the coagulability of the blood, the acid mucopolysaccharide "heparin" also acts as a co-factor in the activation of a lipase which hydrolyses the triglycerides of the blood plasma back into fatty acids. These and 
other similar investigations were the basis for Finley's treatment of diabetic retinopathy by the long-term administration of heparin-a procedure which he reports has given highly encouraging results.

These various studies indicate that, while retinopathies may occur in various disturbances of fat metabolism, their clinical and histological pictures are somewhat different from those of Coats's disease, and that the chief lipid concerned in them is not cholesterol. The blanket inclusion of these ocular histiocytoses under the general classification of Coats's disease has contributed to confusion rather than to clarification. If the term "Coats's disease" is restricted to the retinopathies originally described by him (Groups I and II) and if it is conceded that cholesterol is the chief lipid involved, then the pertinent problem is the possible relationship of Coats's disease to disturbances in the fat metabolism and consideration of the factors which may initiate or facilitate the deposition of cholesterol in the tissues.

\section{(5) Is Coats's disease related to a disorder of the systemic fat metabolism?}

In his original paper Coats described what are commonly known as "cholesterol clefts" and what he believed to be actual cholesterol crystals. He believed that these spaces and crystals were the result of preceding haemorrhage. Bietti (1936), in his study of the deposition of lipids in the eye, pointed out that, while microscopic deposits of cholesterol and fatty acids might well be the result of a prior inflammatory, degenerative, or haemorrhagic reaction, in the larger, macroscopically visible lipid deposits, the lipid originated from the blood plasma. It is interesting, however, that none of the various investigators who noted the presence of lipids in the lesions of Coats's disease specifically demonstrated the exact nature of the lipid, all apparently assuming that it was cholesterol. This assumption has been repeated so often that it is widely accepted as a proven fact. Moreover, no one prior to 1950 associated this probable deposition of cholesterol in Coats's disease with any disturbance in the systemic lipid metabolism.

Lewis (1950) described the clinical picture of the eyes of an adult patient with advanced biliary cirrhosis and a hypercholesteraemia, and 2 years later she reported the histological findings in these eyes when obtained at autopsy (Lewis, 1952). Although she failed to comment on the resemblance, both the clinical and histological pictures in these eyes were identical with those of Coats's disease. Stained sections of these eyes revealed cholesterol clefts and crystals which were presumed to be cholesterol in the subretinal exudate. Sudan III stains revealed foam cells filled with a lipid. This is apparently the only case in which a picture identical to that of Coats's disease has been reported as a complication of a systemic lipidosis and probably related to a proven concomitant hypercholesteraemia. This possible relationship had been suggested by Lamb (1958), but had not been followed up.

(6) What factors may initiate or facilitate the subretinal exudation and the deposition in the retina?

Thannhauser (1958) listed the conditions in which foam cells laden with cholesterol may be found in the systemic tissues:

A. Hypercholesteraemic xanthomatosis and biliary cirrhosis, a condition in which the neutral fats are not increased. 
B. The hyperlipaemic form of xanthomatosis in which the increase in the blood cholesterol is secondary to the increased lipoprotein fraction of the chylomicrons.

C. In the late stages of a xanthomatosis in which the serum cholesterol level is normal.

D. In any tissue which has been the site of prolonged inflammation.

When cholesterol deposition occurs in the presence of a normal cholesteraemia, an explanation must be sought in the consideration of several possibilities-the local synthesis of cholesterol, the influence of a prolonged local inflammation, or the action of some intermediary tissue factor.

Alagna and DiPerri (1955) reported certain blood chemistry studies on a patient with bilateral Coats's disease. All the various estimations were normal except that of the serum globulin which was much reduced. A similar reduction of the globulin fraction was found on analysis of the subretinal fluid. These authors suggested that this change in the chemical constituents of the blood might be related to the aetiology of the ocular disease. Against this supposition is the fact that, in a study of the electrophoretic pattern of the blood serum of patients with uveitis, Woods and Stone (1958) found that, while decreases in the alpha and gamma globulins were more frequent than increases, the difference did not appear significant. Other than this, the suggestion of Alagna and DiPerri does not appear to have been further explored.

The idea that a toxoplasma infection might occasionally be the "trigger mechanism" which initiates the primary subretinal exudation and the consequent separation of the retina and choroid (which appears to be the early step in the pathogenesis of Coats's disease) was advanced by François, Rabaey, Evens, and de Vos (1956). These observers reported a case of Coats's disease in a 3-year-old infant whose blood serum gave strongly positive dye and complement-fixation tests for toxoplasmosis. They discussed the possibility of some relationship between the two diseases. The possibility that there may occasionally be such a trigger relationship is enhanced by the fact that an inflammatory detachment of the retina has already been recognized as an occasional complication in toxoplasmosis; Habeggar (1954) reported the actual isolation of the toxoplasma parasite from the subretinal fluid in such a case, a finding which was confirmed by Jacobs, Melton, Wood, and Woods (1960) by transmission experiments.

Rieger (1960) reviewed his former findings on the probable identity of adult Coats's disease of the macular region, which he termed "external central exudative chorio-retinitis", with toxoplasmic chorio-retinitis. In further support of this idea, he defined the symptomatology of his external central exudative chorioretinitis, and reported fifty randomly selected adult cases, 84 per cent. of which gave positive Sabin-Feldman dye tests in titres of from $1: 16$ to $1: 1,024$. He concluded that such an "adult Coats's disease of the macular region" should be regarded as an ocular infection characteristic of adult acquired toxoplasmosis. He also called attention to the high frequency of chronic tonsillitis and positive Mantoux tuberculin reactions in these patients. He regarded both these conditions as preliminary abnormalities which played a part in the precipitation of the later external central exudative chorio-retinitis.

Rieger's argument for a cause-and-effect relationship between a toxoplasmic infection and Coats's disease is based on the assumption that his "external central exudative retinitis" is truly an adult form of Coats's disease. It is impossible to 
accept this assumption under the criteria for a clinical and histological diagnosis of Coats's disease as outlined below. It appears probable that his central exudative choroiditis is merely the usual toxoplasmic chorio-retinitis so often observed in adults.

This same idea of a relation between Coats's disease and toxoplasmosis was endorsed by Berengo and Frezzotti (1962). Under the title of "acute neuroophthalmic toxoplasmosis" these authors reported nineteen patients with positive dye tests for toxoplasmosis and clinical evidence of both cerebral and ocular changes. In five of these cases the ocular involvement was diagnosed as "typical" Coats's disease, and in four as "external exudative retinitis" suggestive of Coats's disease. On examination of the text and fundus photographs which illustrate this report and in the light of the criteria for both a clinical and histological diagnosis of Coats's disease employed in the present study (see below), one of the "typical" cases must be discarded. However, the other four "typical" cases and one "suggestive" case fulfill the clinical criteria. Three of them occurred from 3 to 18 years after a presumed toxoplasmic chorio-retinitis; one occurred 6 months after a non-perforating injury to the involved eye; the last had no record of preceding inflammation or injury. In several of these cases the toxoplasma parasite was isolated from the centrifuged sediment of the spinal fluid. While this report indicates that some patients with Coats's disease may have a preceding or concomitant toxoplasmic uveitis which may possibly act as a trigger mechanism, it does not suggest any cause-and-effect relationship between the two conditions.

Much more important in the consideration of the aetiology of Coats's disease is the hypothesis that the intermediary action of a mucopolysaccharide may be the factor which initiates the deposition of cholesterol in the tissues. Here there is one contribution so potentially important it merits particular attention.

Faber (1946) reported on the relationship between cholesterol levels in the blood plasma and cholesterol deposits in the aorta. In this paper he demonstrated that, while a hypercholesteraemia acted as an accelerator in the deposition of cholesterol, some factor present in the tissues must be regarded as a prerequisite for such deposition. He later presented a full review of the literature on this subject and the result of further clinical and chemical studies (Faber, 1949). He pointed out that, in patients with a normal cholesteraemia, cholesterol is deposited only in those aortas in which an ethanol-resistant metachromasia is present, and that in such aortas a deposition of cholesterol might be expected. This metachromasia could be demonstrated by metachromatic stains, such as toluidine blue, or by other stains specific for the sulphate-containing polyuronides.

Faber reviewed the previous chemical investigations on the actual nature of the substances responsible for this metachromasia. It had already been established that such metachromasia in the tissues could be caused by the presence of polymerized carbohydrate-containing sulphuric acid esters-heparin, hyaluronic acid, and chondroitin sulphuric acid. In the human aorta in which a deposition of cholesterol had occurred, the metachromatic material was generally assumed to be chondroitin sulphuric acid. In the normal human aorta small amounts of this material were always demonstrable beneath the endothelium of the intima and the intimal portion of the media. In aortas with cholesterol deposits, the amount of this metachromatic material was greatly increased. In experimental rabbbits with epinephrine sclerosis, or in rabbits in which the aortas had been cauterized from 
without, there was likewise a marked increase in the metachromasia, and when these animals were given relatively small doses of cholesterol, deposits of cholesterol occurred at the site of the metachromasia.

In the further study of the relation of this metachromatic material to the deposition of cholesterol, Faber examined fifty human aortas obtained at autopsy from subjects with clinically normal aortas, with hypertensive vascular disease, with syphilitic aortitis, and with hypercholesteraemic xanthomatosis. Acting on the assumption that all the sulphate in these tissues was derived from the metachromatic, polymerized, carbohydrate-containing sulphuric esters, he made estimations of the total sulphate content. He found that this increased with age, in hypertensive vascular disease, and in syphilitic aortitis, and that in all these cases the deposition of cholesterol parallelled the increased sulphate content of the aortas. However, in patients with hypercholesteraemic xanthomatosis, a marked increase in the cholesterol deposits might occur in the aortas with a normal sulphate content. In these cases Faber believed that such deposition was accelerated by the increased amount of cholesterol available from the blood plasma. He discarded completely the idea that cholesterol might be synthesized at the site of deposition and believed all the cholesterol in such deposits was derived from the blood.

Faber's basic idea was that the tissue factor responsible for the transfer of cholesterol from the blood plasma and its deposition in the tissues was the intermediary action of a polymerized, carbohydrate-containing polysaccharide sulphuric acid ester. He imagined that the actual mechanism might be an interaction between such acid polysaccharide esters and the lipoprotein molecules of the blood plasma. As a result of such molecular interchange, there was a liberation of lipid from the lipoprotein molecule with a consequent local deposition of cholesterol in the tissues with the metachromasia. In the presence of a hypercholesteraemia this process might be greatly accelerated.

It is notable that Reese (1956), in his Gifford Lecture, although apparently unaware of Faber's previous work, reached a somewhat similar conclusion. As already noted, Reese suggested that the mucopolysaccharide basement membrane which he demonstrated with the PAS stain beneath the intima of the retinal telangiectases of children, might be the tissue factor concerned in the later development of Coats's disease.

The work of Bragdon and Havel (1954) on heparin and antiheparinoid agents such as protamine is of interest here insofar as it relates to a probable molecular interchange between an acid-polymerized mucopolysaccharide and lipoproteins. Heparin itself has no clearing action on the triglycerides in the blood. It acts through the activation of a lipoprotein lipase. Although the mechanism is imperfectly understood, it appears that the heparin enters into some combination with the lipoprotein molecule to form a substrate on which the lipoprotein lipase may act in the hydrolysis of the triglycerides. This probable molecular interchange is inhibited by such antiheparinoid agents as protamine. Heparin and chondroitin sulphuric acid are both acid mucopolysaccharides and have a similar chemical formula. They may well share this ability to combine with lipoproteins. 


\section{Material and Diagnostic Criteria}

The material on which this study is based consists of eighteen cases of Coats's disease in children aged 16 years or less, and five cases in adults all over 30 years of age. Nine of the juvenile and two of the adult eyes had been enucleated and were thus available for histological study. These cases were assembled by reviewing all the material in the clinical and eye pathology diagnostic files of the Wilmer Institute in which a probable diagnosis of Coats's disease had been made or suggested. Only those cases which met the following clinical and histological criteria were accepted for this study.

Clinical Diagnosis.-The basic criterion for a clinical diagnosis was the presence of a deep yellowish or yellowish-white massive exudate in and beneath the external retina, over which the retinal vessels coursed cleanly without obscuration, and which had produced a localized apparently solid elevation of the retina. In addition to the massive exudate, there might also be isolated focal exudates, but all cases in which the external retinopathy had not produced an actual elevation of the retina were excluded. Similarly excluded were all cases in which there were clinical findings to which the elevation of the retina could be attributed: i.e. an actual hole in the retina, inflammatory changes in the vitreous, traction bands, cyclitic membranes, or other such conditions. However, cases in which the eyes showed anterior segment changes indicative of a former or present iritis were accepted, provided they fulfilled the other diagnostic criteria. A number of the accepted cases showed vascular changes; i.e. telangiectases, miliary aneurysms, kinks, loops, dilated vessels, and haemorrhages. In others, these vascular changes were not noted, it being specifically recorded in the histories that the retinal vascular pattern appeared normal.

Fig. 1 (opposite), a fundus photograph from a young child (Case 18), and Fig. 2 (opposite), from an adult (Case 1), illustrate what is here regarded as the typical exudation of Coats's disease.

Histological Diagnosis.-The criterion was the presence of a massive exudate in the external retina and in the subretinal space. The retinal exudate uniformly contained "foam" or "balloon" cells with a foamy cytoplasm. In all the cases here reported except one, the subretinal mass was at least in part organized with fibrous tissue and invariably contained cholesterol clefts, aggregates of foam-filled cells, and haemosiderin pigment. The one exception was the eye of a 17-month-old infant (Case 12) in which the subretinal mass was not organized. In this case it was believed that there had been insufficient time for organization of the subretinal exudate to occur.

Obliterative retinal vascular changes, perivasculitis, and retinal vascular abnormalities such as telangiectases were often present but were not prerequisite criteria for the diagnosis. In a few cases there were areas of localized atrophy of the choroid and minor inflammatory changes of the nongranulomatous type at points of adhesions between the choroid and the 


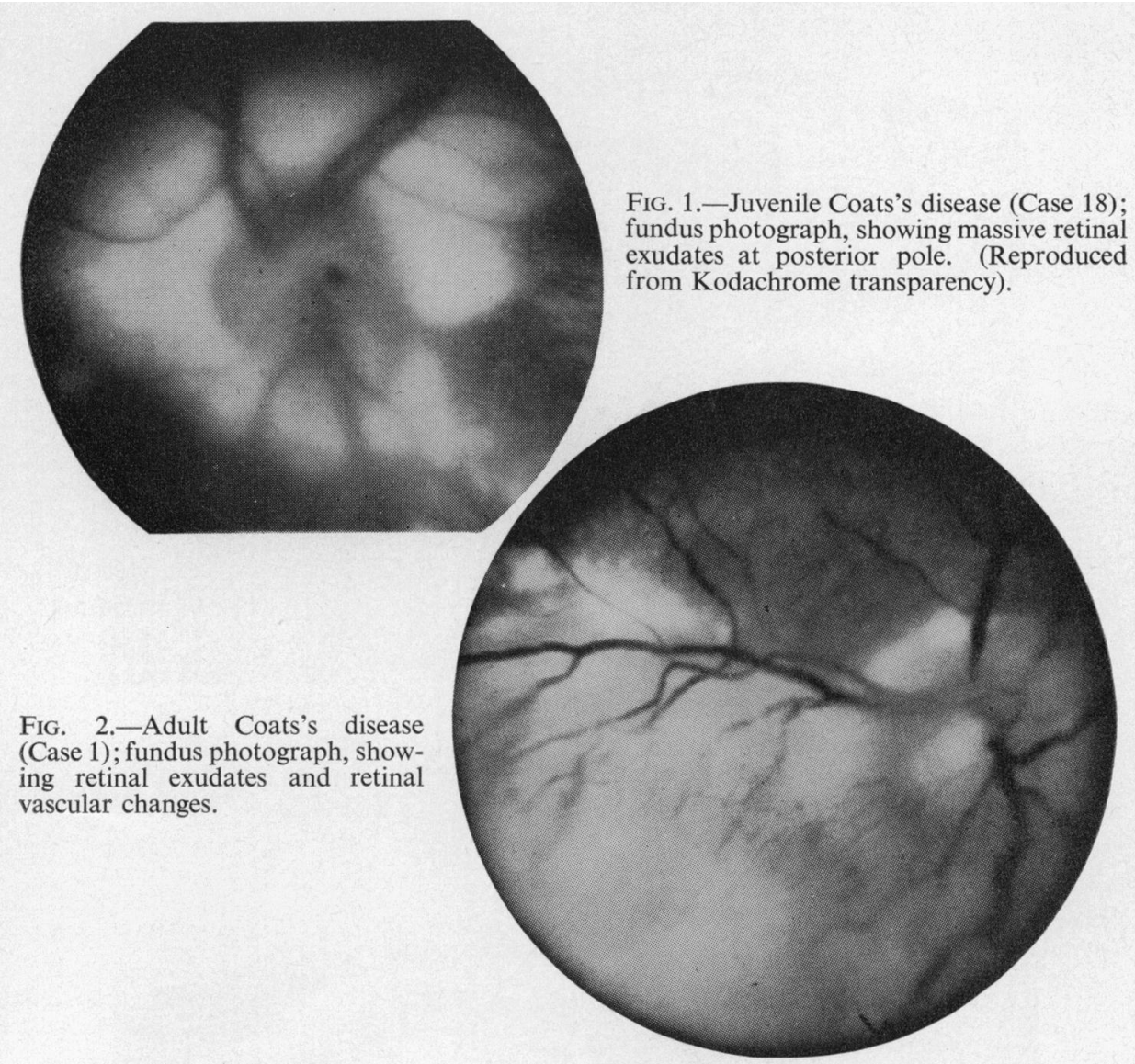

overlying subretinal mass, but in no instance were these inflammatory changes so marked as to suggest a choroiditis as the basic cause of the subretinal exudation. A few of the accepted cases showed evidence of an old or active low-grade inflammation of the anterior uvea, but all cases in which the eyes showed cyclitic membranes, marked inflammatory foci in the uveal tract, traction bands in the vitreous, or other pathological changes which might conceivably account for retinal detachment were rejected for this study.

The observed histopathological changes were the same in both the juvenile and in the adult cases. Figs 3 and 4 (overleaf) from juvenile cases (Nos 15 and 11), and Figs 5 and 6 (overleaf) from an adult (No. 2), illustrate these characteristic changes.

\section{Clinical Observations}

Primarily, it is emphasized that ophthalmoscopic examination revealed no significant or essential difference between the juvenile and the adult cases. In both groups there was the same typical yellowish or yellowish-white 


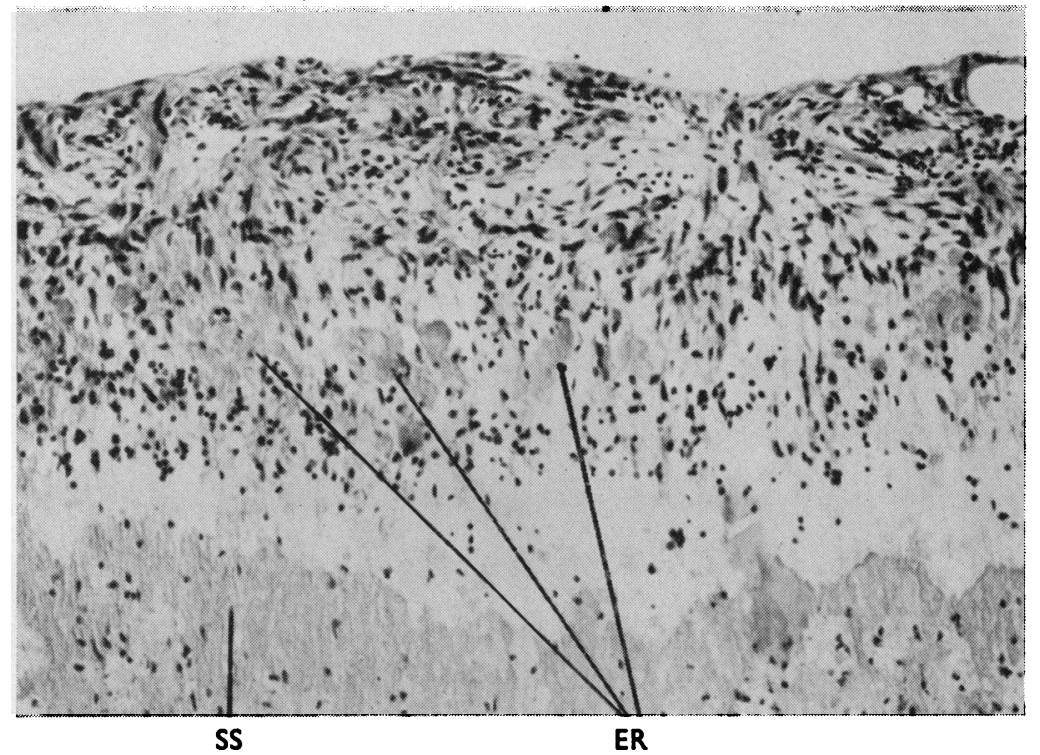

FIG. 3.-Juvenile Coats's disease (Case 15), showing massive exudation in external retina (ER) and in subretinal space (SS). Haematoxylin and eosin. $\times 32$.

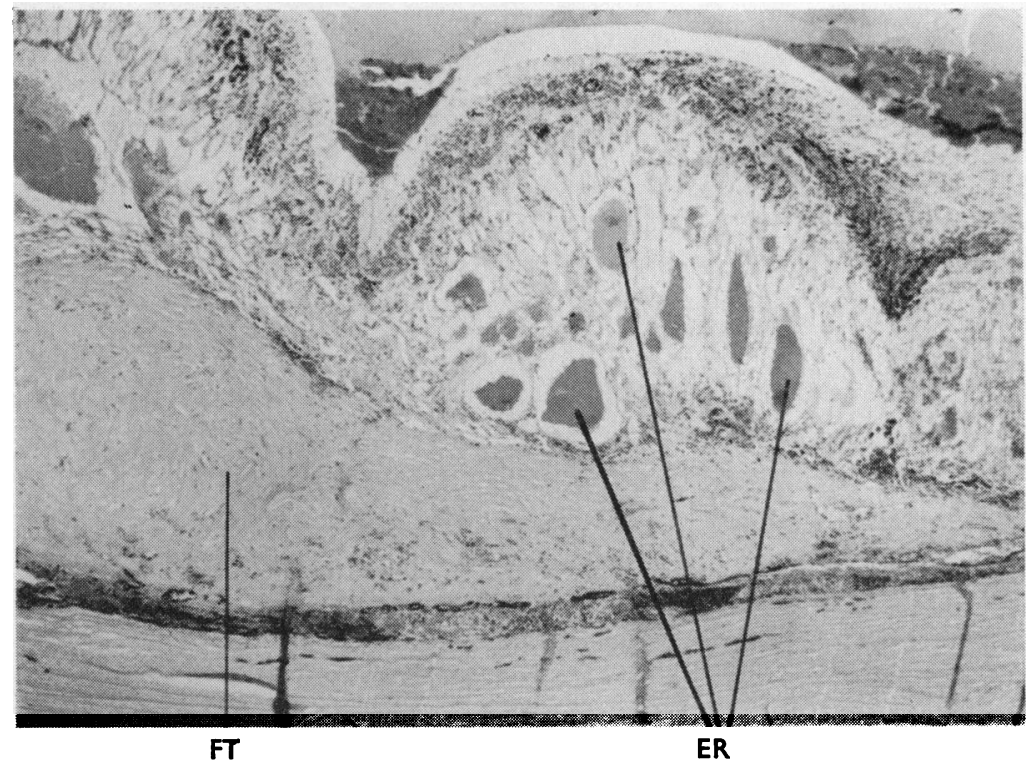

FIG. 4.-Juvenile Coats's disease (Case 11), showing exudates in external retina (ER) and organized fibrous tissue mass (FT) in subretinal space. Haematoxylin and eosin. $\quad \times 6$. 


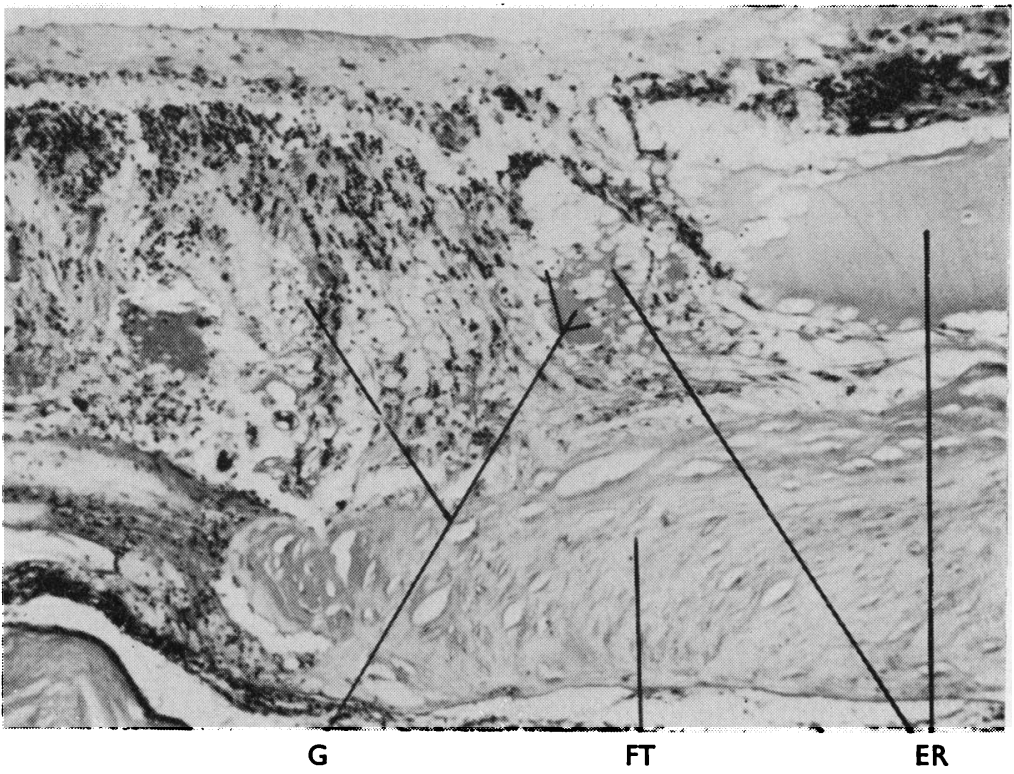

FIG. 5.-Adult Coats's disease (Case 2), showing exudates in external retina (ER), "ghost cells" (G), and organized fibrous tissue mass (FT) in subretinal space. Haematoxylin and eosin. $\times 20$

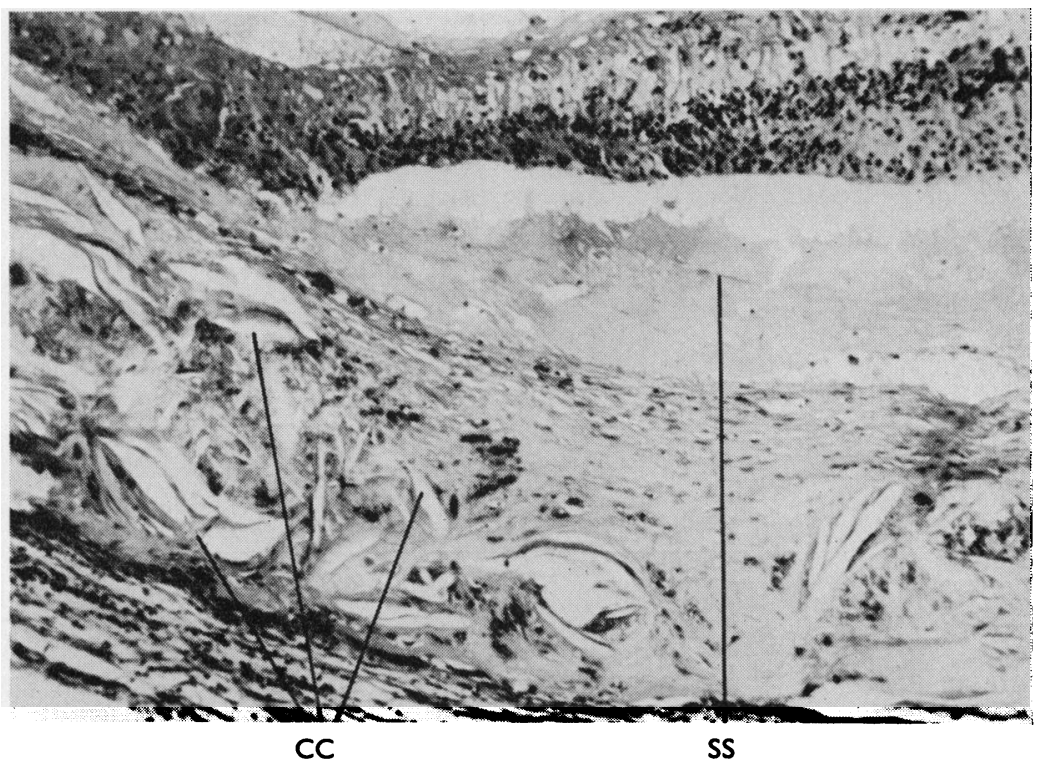

Fig. 6.-Adult Coats's disease (Case 2), showing exudate in subretinal space (SS) and organized subretinal plaque containing cholesterol clefts (CC). Haematoxylin and eosin. $\times 20$. 
massive exudation, with a solid elevation of the retina. Such clinical differences as evidence of an earlier uveal inflammation, vascular changes, etc., as might exist between the juvenile and adult cases, are outlined below.

Juvenile Coats's Disease.-The clinical data for Cases 1-9, in which the eyes were not enucleated, are given in Table I.

TABLE I

CLINICAL DATA ON NINE PATIENTS WITH JUVENILE COATS'S DISEASE DIAGNOSED CLINICALLY

\begin{tabular}{|c|c|c|c|c|c|c|c|c|}
\hline No. & $\begin{array}{l}\text { Age } \\
\text { When } \\
\text { First } \\
\text { Seen }\end{array}$ & Sex & $\begin{array}{l}\text { Unilat. } \\
\text { Bilat. }\end{array}$ & $\begin{array}{l}\text { Vascular } \\
\text { Changes }\end{array}$ & $\begin{array}{l}\text { History, Survey, } \\
\text { Ocular Findings }\end{array}$ & $\begin{array}{l}\text { Dye } \\
\text { Test }\end{array}$ & $\begin{array}{l}\text { Lipid } \\
\text { Studies }\end{array}$ & Notes \\
\hline 1 & $\begin{array}{c}12 \\
9 / 26 / 32\end{array}$ & $\mathbf{M}$ & Unilat. & Yes & $\begin{array}{l}\text { Ant. seg. neg. } \\
\text { Survey neg. }\end{array}$ & $\begin{array}{l}\text { Not } \\
\text { done }\end{array}$ & None & \\
\hline 2 & $\begin{array}{c}7 \\
9 / 6 / 43\end{array}$ & $\mathbf{M}$ & Unilat. & None & $\begin{array}{l}\text { Ant. seg. neg. } \\
\text { Survey neg. }\end{array}$ & $\begin{array}{l}\text { Not } \\
\text { done }\end{array}$ & None & \\
\hline 3 & $\begin{array}{c}6 \\
11 / 7 / 48\end{array}$ & F & Unilat. & None & $\begin{array}{l}\text { Old iritis. } \\
\text { Old fine keratic } \\
\text { precipitates } \\
\text { Posterior } \\
\text { synechiae } \\
\text { Survey neg. }\end{array}$ & $\begin{array}{l}\text { Not } \\
\text { done }\end{array}$ & None & $\begin{array}{l}\text { Diathermy } \\
\text { ineffective }\end{array}$ \\
\hline 4 & $\begin{array}{c}6 \\
3 / 19 / 50\end{array}$ & $\mathbf{M}$ & Unilat. & Yes & $\begin{array}{l}\text { Ant. seg. neg. } \\
\text { Survey neg. }\end{array}$ & Neg. & None & $\begin{array}{l}\text { Diathermy and } \\
\text { steroid therapy } \\
\text { ineffective }\end{array}$ \\
\hline 5 & $\begin{array}{c}8 \\
10 / 4 / 50\end{array}$ & $\mathbf{M}$ & Bilat. & None & $\begin{array}{l}\text { Ant. seg. neg. } \\
\text { Survey not done }\end{array}$ & $\begin{array}{l}\text { Not } \\
\text { done }\end{array}$ & None & \\
\hline 6 & $\begin{array}{c}8 \\
6 / 10 / 51\end{array}$ & $\mathbf{M}$ & Unilat. & Yes & $\begin{array}{l}\text { Ant. seg. neg. } \\
\text { Survey neg. }\end{array}$ & Neg. & None & \\
\hline 7 & $\begin{array}{c}9 \\
11 / 25 / 55\end{array}$ & F & Unilat. & Yes & $\begin{array}{l}\text { Ant. seg. neg. } \\
\text { Prothrombin } \\
\text { decreased }\end{array}$ & Neg. & Yes & $\begin{array}{l}\text { Diathermy in- } \\
\text { effective } \\
\text { Iridocyclitis } \\
\text { developed }\end{array}$ \\
\hline 8 & $\begin{array}{c}11 \\
3 / 9 / 56\end{array}$ & $F$ & Unilat. & Yes & $\begin{array}{l}\text { Ant. seg. neg. } \\
\text { Prothrombin } \\
\text { decreased }\end{array}$ & Neg. & None & $\begin{array}{l}\text { Steroid therapy } \\
\text { ineffective }\end{array}$ \\
\hline 9 & $\begin{array}{c}11 \\
2 / 8 / 59\end{array}$ & $F$ & Unilat. & Yes & $\begin{array}{l}\text { Ant. seg. neg. } \\
\text { Survey neg. }\end{array}$ & $\begin{array}{l}\text { Pos. } \\
1: 256\end{array}$ & None & $\begin{array}{l}\text { Diathermy in- } \\
\text { effective } \\
\text { Vision decreased }\end{array}$ \\
\hline
\end{tabular}

Those for Cases 10-18, in which the clinical diagnosis was confirmed by histological examination, are given in Table II (opposite).

Taken as a group, the average age of these eighteen patients when first examined was 8 years. The youngest was aged 9 months and the oldest 12 years. There were eleven boys and seven girls. The disease was unilateral in fifteen patients and bilateral in three (Cases 5, 10,14). There were definite vascular changes in twelve, and a superficial retinal haemorrhage was 
TABLE II

CLINICAL DATA ON NINE PATIENTS WITH JUVENILE COATS'S DISEASE DIAGNOSED CLINICALLY AND HISTOLOGICALLY

\begin{tabular}{|c|c|c|c|c|c|c|c|c|}
\hline No. & $\begin{array}{l}\text { Age } \\
\text { When } \\
\text { First } \\
\text { Seen }\end{array}$ & Sex & $\begin{array}{c}\text { Unilat. } \\
\text { Bilat. }\end{array}$ & $\begin{array}{l}\text { Vascular } \\
\text { Changes }\end{array}$ & $\begin{array}{l}\text { History, Survey, } \\
\text { Ocular Findings }\end{array}$ & $\begin{array}{l}\text { Dye } \\
\text { Test }\end{array}$ & $\begin{array}{l}\text { Lipid } \\
\text { Studies }\end{array}$ & Notes \\
\hline 10 & \begin{tabular}{c|c}
8 \\
$8 / 5 / 41$
\end{tabular} & F & Bilat. & Yes & $\begin{array}{l}\text { Ant. seg. neg. } \\
\text { Survey neg. }\end{array}$ & $\begin{array}{l}\text { Not } \\
\text { done }\end{array}$ & $\begin{array}{l}\text { Plasma } \\
\text { choles. } \\
\text { only }\end{array}$ & $\begin{array}{l}\text { Followed } \\
\text { chicken pox }\end{array}$ \\
\hline 11 & $\begin{array}{c}11 \\
9 / 21 / 42\end{array}$ & $\mathbf{M}$ & Unilat. & Yes & $\begin{array}{l}\text { Old fine keratic } \\
\text { precipitates } \\
\text { No Survey }\end{array}$ & $\begin{array}{l}\text { Not } \\
\text { done }\end{array}$ & None & \\
\hline 12 & $\begin{array}{l}9 \mathrm{mths} \\
12 / 9 / 47\end{array}$ & $\mathbf{M}$ & Unilat. & Yes & Ant. seg. neg. & $\begin{array}{l}\text { Not } \\
\text { done }\end{array}$ & None & $\begin{array}{l}\text { Serous exudate } \\
\text { beneath retina }\end{array}$ \\
\hline 13 & $\begin{array}{c}7 \\
2 / 25 / 54\end{array}$ & $\mathbf{M}$ & Unilat. & Yes & Ant. seg. neg. & Neg. & Yes & $\begin{array}{l}\text { Nematode } \\
\text { larvae in stool }\end{array}$ \\
\hline 14 & $9 \mathrm{mths}$ & $\mathbf{M}$ & Bilat. & Yes & $\begin{array}{l}\text { Ant. seg. neg. } \\
\text { Survey neg. }\end{array}$ & Neg. & Yes & $\begin{array}{l}\text { Left eye only } \\
\text { enucleated }\end{array}$ \\
\hline 15 & 4 & $\mathbf{M}$ & Unilat. & Yes & $\begin{array}{l}\text { Ant. seg. neg. } \\
\text { Survey neg. }\end{array}$ & Neg. & Yes & $\begin{array}{l}\text { Followed acute } \\
\text { febrile illness }\end{array}$ \\
\hline 16 & 11 & $\mathbf{M}$ & Unilat. & Yes & $\begin{array}{l}\text { Ant. seg. neg. } \\
\text { Survey neg. }\end{array}$ & Neg. & Yes & \\
\hline 17 & 2 & $\mathbf{F}$ & Unilat. & Yes & $\begin{array}{l}\text { Evidences of old } \\
\text { iritis } \\
\text { Survey neg. }\end{array}$ & Neg. & Yes & $\begin{array}{c}\text { Active iritis at } \\
\text { time of first } \\
\text { examination }\end{array}$ \\
\hline 18 & $\begin{array}{c}11 \\
1 / 13 / 61\end{array}$ & F & Unilat. & None & $\begin{array}{l}\text { Ant. seg. neg. } \\
\text { Survey neg. }\end{array}$ & $\begin{array}{l}\text { Not } \\
\text { done }\end{array}$ & $\begin{array}{l}\text { Not } \\
\text { done }\end{array}$ & \\
\hline
\end{tabular}

noted in one other, the retinal vessels being recorded as normal in the other five. Two patients showed organic evidence of a preceding iritis: one (Case 17) had an active iritis at the time of the initial examination, and one (Case 7) developed a recurrent, nongranulomatous iridocyclitis with band keratopathy 5 years after the onset of Coats's disease.

Diagnostic surveys were carried out in fourteen of these patients. Two gave a history of an immediately preceding illness (undiagnosed in one (Case 15) and chicken-pox in the other (Case 10)). One (Case 14) had multiple telangiectases of the skin similar to the vascular changes in the retina. Two others (Cases 7 and 8), both with vascular changes and haemorrhages in the retina, had low prothrombin titres in the blood serum. One (Case 13) had nematode larvae in the stool, but none could be found in the enucleated eye. Sabin-Feldman dye tests, which were done on ten of these eighteen children, were negative in nine and positive in one. In ten patients both the histories and the medical surveys were negative (Cases 1, 2, 4, 5, 9, 10, 14, 15, 16, 18).

Four of these eighteen children (Cases 3, 4, 7,9) had been treated with surface diathermy over the massive retinal exudates. In three this therapy 
was totally without effect. In the fourth (Case 9), it was followed by a shrinkage of the exudate, a regression of the vascular changes, and finally retinal gliosis. However, the visual acuity fell from a pre-operative level of $20 / 200$ to a post-operative level of 20/400 minus. Intensive corticosteroid therapy had been administered to two of these patients (Cases 4,8 ) with no effect on the retinopathy.

Adult Coats's Disease.-The basic clinical data for the five adult patients with Coats's disease as here defined are given in Table III. In three (Cases $2,3,5)$ there was an authenticated history of a preceding nongranulomatous uveitis. In two (Cases 1 and 4 ) the dye and skin tests for toxoplasmosis were positive: in one there was a definite history of a chorio-retinitis a few months before the development of the symptomatology of Coats's disease, and in the other there was a history of a preceding anterior uveitis with secondary glaucoma.

TABLE III

CLINICAL DATA ON FIVE ADULT PATIENTS WITH COATS'S DISEASE

\begin{tabular}{|c|c|c|c|c|c|c|c|c|c|}
\hline \multirow[t]{2}{*}{$\begin{array}{c}\text { Case } \\
\text { No. }\end{array}$} & \multirow[t]{2}{*}{ Sex } & \multirow{2}{*}{$\begin{array}{l}\text { Age } \\
\text { First } \\
\text { Seen } \\
\text { (yrs) }\end{array}$} & \multicolumn{2}{|c|}{$\begin{array}{l}\text { Age at Onset } \\
\text { of Uveitis } \\
\text { (yrs) }\end{array}$} & \multicolumn{2}{|c|}{$\begin{array}{l}\text { Interval before } \\
\text { Onset of Coats's } \\
\text { Disease (yrs) }\end{array}$} & \multirow{2}{*}{$\begin{array}{c}\text { Distribution } \\
\text { of } \\
\text { Coats's Disease }\end{array}$} & \multirow{2}{*}{$\begin{array}{l}\text { Vascular } \\
\text { Changes } \\
\text { Present }\end{array}$} & \multirow[t]{2}{*}{$\begin{array}{c}\text { Systemic } \\
\text { Disease }\end{array}$} \\
\hline & & & $\mathbf{R}$ & $\mathrm{L}$ & $\mathbf{R}$ & $\mathbf{L}$ & & & \\
\hline 1 & $\mathbf{M}$ & 62 & 73 & 62 & $?$ & $2 \mathrm{mths}$ & Bilateral & Yes & $\begin{array}{l}\text { Toxoplasmosis } \\
\text { (dye test } \\
\text { positive) }\end{array}$ \\
\hline 2 & F & 71 & & 67 & & $3-4$ & Unilateral & Yes & $\begin{array}{l}\text { Advanced } \\
\text { arteriosclerosis }\end{array}$ \\
\hline 3 & $\mathbf{F}$ & 54 & 41 & 43 & 7 & $3 \mathrm{mths}$ & Bilateral & Yes & $\begin{array}{l}\text { Apically in- } \\
\text { fected teeth } \\
\text { Bacterial } \\
\text { hyper- } \\
\text { sensitivity }\end{array}$ \\
\hline 4 & $\mathbf{F}$ & 43 & 42 & & $\begin{array}{l}6 \text { to } 12 \\
\text { mths }\end{array}$ & & Unilateral & Yes & $\begin{array}{l}\text { Toxoplasmosis } \\
\text { (dye test } \\
\text { positive) }\end{array}$ \\
\hline 5 & $\mathbf{M}$ & 33 & 14 & 14 & 18 & $4(?)$ & Unilateral (?) & None & $\begin{array}{l}\text { Fatty meta- } \\
\text { morphosis } \\
\text { of liver }\end{array}$ \\
\hline
\end{tabular}

In two (Cases 1,3) the Coats's disease was bilateral, and in both there was a history of a preceding bilateral uveitis. In the third patient with a history of bilateral uveitis (Case 5) the presence or absence of Coats's disease in the second eye could not be determined on account of a secondary cataract. In Cases 2 and 4 the Coats's disease was unilateral and occurred in the eye with the preceding uveal inflammation. When the diagnosis of Coats's disease 
was first made in these five patients, the youngest was 33 and the oldest 65 years old. The interval between the preceding uveitis and the development of the symptomatology of Coats's disease was usually impossible to determine accurately. In one case it was less than 9 months, while in the others it was probably as long as several years. Gross retinal vascular changes were present in four patients, but in Case 5 no such changes could be detected. In Cases 1 and 2 the involved eye had been enucleated and in Case 2 the diagnosis was first made on histological examination. Four of these five patients had received somewhat intensive steroid therapy without any effect other than a transient control of the acute symptoms of the nongranulomatous iridocyclitis.

\section{These five adult cases may be summarized as follows:}

Case 1, a 62-year-old white male, with a history of prolonged, mild hypertensive vascular disease, developed pain and inflammation in the left eye in February, 1947. About 2 months later he experienced a loss of depth perception. Fundus examination at that time showed a yellowish, slightly elevated exudate in the deep retina with smaller surrounding exudates and a deep choroidal haemorrhage. The lesion progressed, and in 1949 examination of the eye revealed posterior synechiae, evidences of an old iritis, and a glistening yellowish mass in the subretinal space with an 11-dioptre elevation of the retina. Vision had fallen to perception of light. The tentative clinical diagnosis was Coats's disease. The eye became painful and was enucleated in 1949, when histological examination confirmed the clinical diagnosis. Examination of the right eye in 1954 and 1956 showed no abnormality. However, in 1958, the patient returned with the complaint of redness in the right eye and sharply failing vision. Examination showed a picture almost exactly the same as that of the left eye in 1949, with vision reduced to $4 / 200$ and the classical picture of Coats's disease in the fundus (Fig. 2). The plasma lipids were now determined and showed a marked elevation (see Table V). The Sabin-Feldman dye test for toxoplasmosis was positive.

Case 2, a 71-year-old coloured female, was first admitted to the Wilmer Institute in August, 1951 , with a blind painful eye. There was a history of an injury to this eye 3 to 4 years previously, followed by prolonged inflammation and the gradual development of a cataract and secondary glaucoma. The eye was enucleated. The histological picture was classical Coats's disease (Figs 5 and 6). The medical consultation revealed chronic hypertensive vascular disease with an arteriolar sclerotic nephropathy. The patient died 3 months later. There were no plasma lipid studies in this case.

Case 3, a 54-year-old white female, was admitted to the Wilmer Institute in February, 1958. In 1945, after some obscure "tropical disease", the right eye suffered what was apparently a central serous retinopathy which destroyed all useful vision. Sometime between 1952 and 1956 this eye developed an external retinopathy characterized by a yellowish mass in the retina and subretinal space. In 1957 the left eye developed an acute nongranulomatous iridocyclitis which gradually yielded to steroid therapy within 4 months. An external retinopathy, similar to that in the right eye, then developed with vision reduced to 20/200. At this time both fundi showed the clinical picture of Coats's disease. The medical survey revealed several apically infected teeth and a moderate hypersensitivity to various streptococcal antigens. The plasma lipids were notably elevated (Table V). 
Case 4, a 43-year-old white female, was first seen in November, 1960. The past history was noncontributory, with the possible exception that the patient had worked a great deal with domestic animals. One year previously she had developed some visual failure in the right eye with heavy veiling, but no external inflammation. A few months later she consulted a local ophthalmologist who noted some vascular changes and haemorrhages in the retina. In the temporal fundus, the retina was elevated and showed subretinal exudation highly suggestive of Coats's disease. The medical survey was negative except for a strongly-positive skin reaction to toxoplasmin, a dye test positive in a titre of $1: 32$, and a weakly-positive reaction to histoplasmin, but a negative complement-fixation reaction. There was an elevation of the plasma lipids, especially of the blood cholesterol. Despite antitoxoplasmic therapy, the condition progressed and the eye developed the typical picture of Coats's disease.

Case 5, a 33-year-old white male, was admitted to the Wilmer Institute in April, 1961. He had suffered his first attack of bilateral iridocyclitis at the age of 14 . There were numerous recurrences, several of which were associated with a bilateral central serous retinopathy. By 1946, when the patient was 18 years old, the left eye was blind with a secondary cataract and a partially-occluded pupil. The fundus could no longer be seen, and the presence or absence of Coats's disease was never determined. In 1960 the referring ophthalmologist first noticed yellowish, focal exudates in the right fundus. By 1961 these had coalesced and there was a localized detachment or elevation of the retina over which the vessels coursed cleanly without obscuration. There were no vascular changes or haemorrhages. The medical survey showed an apical infection of several teeth which were extracted and from which streptococci were isolated. The patient was hypersensitive to vaccines prepared from these autogenous organisms. The liver and spleen were palpable; there was a 28 per cent. retention of bromsulphalein; a liver biopsy showed fatty metamorphosis; and there was a marked elevation of the plasma lipids, especially cholesterol.

\section{Plasma Lipid Studies}

Normal Plasma Lipids.-The chief lipid components of the blood plasma are the total cholesterol (the free cholesterol plus the cholesterol esters), the phospholipids, and the neutral fats. The sum of these lipids, with other minor fractions, is known as the "total plasma lipids". The normal concentration of these lipids in the plasma is given by Boyd (1933) as follows:

\begin{tabular}{lc}
\multicolumn{1}{c}{ Plasma lipids } & mg. per cent. \\
Total plasma lipids & 589 \\
Free cholesterol & 47 \\
Cholesterol esters & 192 \\
Total phospholipids & 196 \\
Neutral fats & 154
\end{tabular}

The triglycerides account for about 95 per cent. of the neutral fats.

Thannhauser has emphasized that, under physiological conditions such as fasting, dieting, etc., there may be considerable variation in the plasma 
lipids, especially in the neutral fats, and gives the following figures for these variations:

$\begin{array}{lc}\text { Plasma lipids } & \text { Variation } \text { (mg. per cent.) } \\ \text { Total cholesterol } & 150-260 \\ \text { Total phospholipids } & 150-250 \\ \text { Neutral fats } & 0-400 \\ \text { Ratio of free cholesterol to the cholesterol esters } 1: 3 \text {. }\end{array}$

According to these figures, varying with fasting or the ingestion of fats, the total lipids may vary from a minimum of 300 to a maximum of $910 \mathrm{mg}$. per cent. In general, without a known ingestion of fatty foods before taking the blood for the chemical determinations, a total plasma lipid of over 600 mg. per cent, and a cholesterol of over 260 to $300 \mathrm{mg}$. per cent. are regarded as indicative of a disturbance in the fat metabolism. For all practical purposes the plasma lipids can be adequately explored by a determination of the total lipids, the total cholesterol, and the total phospholipids. The neutral fat content of the plasma is determined by deducting the sum of the total cholesterol and phospholipids from the total lipids.

Chemical Determinations in Coats's Disease.-The determinations here reported were all made in the clinical chemical laboratory of the Medical Department of the Johns Hopkins Hospital. The total lipids, determined by the method of Bloor (1915), represent the total weight of all ether-extractable fats. The total cholesterol, determined by a modification of Bloor's original method, represents the sum of the free cholesterol and the cholesterol esters. The total phospholipids were determined by the Youngburg method (1930). The neutral fats were calculated by deducting the total cholesterols and phospholipids from the total lipids.

Juvenile Coats's Disease.-The plasma lipid determinations in nine cases of juvenile Coats's disease are given in Table IV (overleaf). In every case the plasma lipids were within normal limits. In one case the total lipids were $670 \mathrm{mg}$. per cent., because of a slight increase in the neutral fats, the cholesterols and the phospholipids being normal. It is thus impossible in these cases to attribute any deposition of lipids in the retina or sub-retinal space to a hypercholesteraemia. Any such deposition in patients with a normal blood plasma cholesterol content must be due either to the irritation of chronic inflammation, to the intra-cellular synthesis of cholesterol (as suggested by Thannhauser), or to the intermediary action of some tissue factor, as suggested by Faber. Certainly, juvenile Coats's disease cannot be explained on the grounds of a basic elevation in the plasma lipids.

Adult Coats's Disease.-The plasma lipid studies in the four adult patients with Coats's disease, on whom such studies were done, are given in Table V (overleaf). 
TABLE IV

PLASMA LIPIDS (MG. PER CENT.) IN NINE CHILDREN AND INFANTS WITH COATS'S DISEASE

\begin{tabular}{c|c|c|c|c}
\hline \multirow{2}{*}{$\begin{array}{c}\text { Case } \\
\text { No. }\end{array}$} & \multicolumn{3}{|c|}{ Chemical Determinations } & Calculated \\
\cline { 2 - 4 } & $\begin{array}{c}\text { Total } \\
\text { Lipids }\end{array}$ & $\begin{array}{c}\text { Total } \\
\text { Cholesterols }\end{array}$ & $\begin{array}{c}\text { Total } \\
\text { Phospholipids }\end{array}$ & - \\
\hline 10 & - & 160 & - & 135 \\
\hline 13 & 550 & 240 & 175 & 38 \\
\hline 14 & 430 & 192 & 200 & 30 \\
\hline 15 & 450 & 220 & 200 & 10 \\
\hline 7 & 410 & 210 & 190 & 0 \\
\hline 8 & 320 & 184 & 150 & 165 \\
\hline 16 & 540 & 200 & 175 & 247 \\
\hline 9 & 670 & 210 & 213 & 139 \\
\hline 17 & 510 & 184 & 187 & \\
\hline
\end{tabular}

TABLE V

PLASMA LIPIDS (MG. PER CENT.) IN FOUR ADULT PATIENTS WITH COATS'S DISEASE

\begin{tabular}{c|c|c|c|c}
\hline \multirow{2}{*}{$\begin{array}{c}\text { Case } \\
\text { No. }\end{array}$} & \multicolumn{3}{|c|}{ Chemical Determinations } & $\begin{array}{c}\text { Calculated } \\
\text { Neutral Fats }\end{array}$ \\
\cline { 2 - 4 } & $\begin{array}{c}\text { Total } \\
\text { Lipids }\end{array}$ & $\begin{array}{c}\text { Total } \\
\text { Cholesterols }\end{array}$ & $\begin{array}{c}\text { Total } \\
\text { Phospholipids }\end{array}$ & 250 \\
\hline 1 & 1140 & 336 & 350 & 454 \\
\hline 3 & 1040 & 325 & 300 & 0 \\
\hline 4 & 650 & 350 & 340 & 260 \\
\hline 5 & 950 & 350 & 310 & 320 \\
\hline Averages & 945 & 340 & & \\
\hline
\end{tabular}

In these patients the total cholesterols were definitely raised to a pathological level-an average of $340 \mathrm{mg}$. per cent. against a normal maximum of 260 to $300 \mathrm{mg}$. In these four patients the elevation of the phospholipids was slightly less marked, being $310 \mathrm{mg}$. per cent. against a normal maximum of $260 \mathrm{mg}$., and the average of the neutral fats was $255 \mathrm{mg}$. per cent., well below the possible normal maximum given by Thannhauser. It is also notable that in Case 4, in which both the total phospholipids and the total cholesterols were definitely elevated, the neutral fats were calculated as zero. These results are shown in Table V. 


\section{Comment}

The review of the literature here reported indicates that Coats himself, and practically all subsequent reporters on the disease which bears his name, were impressed by the so-called cholesterol clefts, the empty foam cells, and the occasional presence of crystals in the external retina and subretinal space. It was generally assumed that the lipid responsible for these changes was cholesterol. It is notable, however, that in no instance was any proof advanced to support this assumption. It is also notable that, with the exception of the single adult case reported by Lewis, no correlation was noted between Coats's disease and a hypercholesteraemia, nor was any evidence adduced of other disturbances in the systemic fat metabolism. On the other hand, such correlation has been noted in the various other lipid retinopathies-in NiemannPick disease, in diabetic retinopathy, and in idiopathic hyperlipaemia. Thus Coats's disease has remained an enigma, almost in a class by itself. The stress laid on the importance of the cholesterol clefts, crystals, and foam cells would almost justify the conclusion that the deposition of cholesterol in the external retina and subretinal space was the essential pathological change which would establish Coats's disease as a clinical and histopathological entity. Yet nowhere does this view appear to have been concretely expressed, much less proven.

A study of the pertinent cases in the literature and those from the Wilmer Institute would indicate that Coats was fully justified and was correct in his division of this external retinopathy into two groups: Group I without manifest vascular changes and Group II with telangiectases, vascular loops, haemorrhages, etc. This again introduces the question whether the vascular changes are the primary cause or the result of the external retinopathy. The undoubted fact that the typical retinopathy may sometimes occur without visible vascular changes, would indicate that the haemorrhages were secondary. On the other hand, the fact that the telangiectases may be the presenting lesion in eyes which later develop Coats's disease, might be interpreted as an indication that the retinopathy is the result of the vascular changes. The logical solution for this enigma is that quite probably other factors initiate both the subretinal exudation and the vascular changes. If this be true, the best explanation is that offered by Wise: that an impairment of the retinal circulation and the separation of the retina from the underlying choriocapillaris, from which it derives the bulk of its oxygen requirements, results in a relative hypoxia of the external retina. This in turn causes a reawakening of the dormant vasoformative mechanism with a resultant neovascularization. The haemorrhages arise from a rupture of the newlyformed capillaries, and are therefore secondary. This explanation is logical and fits the known facts.

Toxoplasma studies were performed in ten of the eighteen juvenile cases shown in Tables I and II, and in four of the five adult cases here reported. 
In nine of the juvenile cases the skin and dye tests were negative, and in one they were positive. In two of the adult cases these tests were positive, and in two they were negative. These findings do not contradict the assumption that toxoplasmosis occasionally may be the trigger mechanism activating the tissue factor which is probably responsible for the deposition of lipid in the retina and subretinal space. However, in children, toxoplasmosis appears to be of little or no importance. In adults it may be more important. It is notable that in the adult Case 4 reported above, in which the skin and dye tests for toxoplasmosis were both positive, an active chorioretinitis had undoubtedly occurred a few months before the development of Coats's symptomatology. However, Rieger's conclusion that adult Coats's disease involving the macular region is due to an acquired toxoplasmosis cannot be accepted. At best an ocular toxoplasmic infection can be no more than the occasional trigger mechanism which activates the tissue factor responsible for the subretinal exudation and lipid deposition which are the characteristics of Coats's disease.

The cases here noted from the literature in which the age and sex of the patient are given, and also those from the Wilmer Institute, lend only weak support to the widely held and oft-repeated statement that Coats's disease is almost invariably unilateral and predominates in young male children. It is true that the disease was unilateral in all the twenty original cases reported by Coats, that twelve patients were aged 19 years or less, and that fifteen were males. However, in the material here summarized, 78 cases are available for analysis. 68 of these were unilateral and ten were bilateral-a ratio of $7: 1$. 62 would be classed as juveniles (under 19 years of age), and sixteen as adults-a ratio of $4: 1$. 51 were males and 27 were females-a ratio of less than 2:1. These figures are shown in Tables VI and VII. Quite evidently the fact that an external retinopathy may be bilateral, or that the patient may be an adult or a female, is not a valid reason for excluding a diagnosis of Coats's disease.

The data here presented offer a logical explanation for the pathogenesis of the adult form of Coats's disease. It may be suggested with reasonable assurance that, in the presence of a hypercholesteraemia, the insult from a preceding uveal inflammation in some way precipitates the deposition of cholesterol in the retina and subretinal space. This is in full accord with what is known and accepted concerning the deposition of cholesterol in chronically inflamed tissues, and is witnessed by the occurrence of masses of foam cells in chronic osteomyelitis, in chronic cholecystitis, in the walls of old abscesses, and even in scars and pock marks. The four adult patients with Coats's disease here reported on whom lipid studies were done all had a hypercholesteraemia and all had suffered some form of preceding uveal inflammation. In the unilateral cases Coats's disease developed only in the eyes which had been the site of such prior uveal inflammation. 
TABLE VI

DISTRIBUTION AND SEX IN CASES OF JUVENILE COATS'S DISEASE

\begin{tabular}{l|c|c|c|c|c}
\hline \multicolumn{1}{c|}{ Source } & No. of Cases & Unilateral & Bilateral & Male & Female \\
\hline Coats (1908) & 12 & 12 & 0 & 10 & 2 \\
\hline Subsequent Reports & 32 & 29 & 3 & 21 & 11 \\
\hline Woods and Duke & 18 & 15 & 3 & 11 & 7 \\
\hline \multicolumn{1}{c}{ Totals } & 62 & 56 & 6 & 42 & 20 \\
\hline
\end{tabular}

TABLE VII

DISTRIBUTION AND SEX IN ADULT CASES OF COATS'S DISEASE

\begin{tabular}{l|c|c|c|c|c}
\hline \multicolumn{1}{c|}{ Source } & No. of Cases & Unilateral & Bilateral & Male & Female \\
\hline Coats (1908) & 8 & 8 & 0 & 5 & 3 \\
\hline Subsequent Reports & 3 & 2 & 1 & 2 & 1 \\
\hline Woods and Duke & 5 & 2 & 3 & 2 & 3 \\
\hline Totals & 16 & 12 & 4 & 9 & 7 \\
\hline
\end{tabular}

As a control for the conclusion that in adult patients a hypercholesteraemia is the prerequisite which permits a uveal inflammation to initiate the deposition of cholesterol in the eye and the development of Coats's disease, cholesterol determinations were made on the blood plasma of 35 consecutive adult patients with repeated or protracted attacks of uveitis, who showed no symptoms suggestive of Coats's disease. In 31 of these patients ( 89 per cent.) the blood cholesterol was within normal limits, and in only four (11 per cent.) was it elevated. This is certainly not an abnormal ratio for a hypercholesteraemia in adults.

This hypothesis for the pathogenesis of Coats's disease in adults does not answer the question whether the ocular inflammation in the presence of hypercholesteraemia, initiates per se the deposition of cholesterol in the ocular tissues, or whether it causes the activation of a tissue factor which, through its intermediary action, is responsible for the actual deposition of cholesterol. When the similarity of the clinical and histological lesions of the juvenile and adult forms of the disease are considered, it would seem logical that the intermediary action of some mutual factor, present in both juvenile and adult eyes, is the logical explanation.

The studies thus far reported give no real intimation of the factor or factors concerned in the pathogenesis of the juvenile form of Coats's disease. In all the nine juvenile cases in which the plasma lipids were determined, the results, including the total cholesterol, were normal. Neither a hypercholesteraemia, a preceding uveitis, nor any systemic illness would be 
incriminated. Only two of the eighteen children had a history of a preceding febrile illness, and only one had positive tests for toxoplasmosis-findings certainly not remarkable in any group of eighteen children. Thus these can scarcely be the precipitating factors. The possible explanation offered by Thannhauser that the cholesterol is synthesized by the assembled histiocytes likewise appears inapplicable. It is more probable that the histiocytes are mobilized from the reticulo-endothelial system for their routine job of phagocytosing already deposited particulate matter. Such mobilization would therefore be a secondary and not a primary phenomenon. If preceding ocular inflammation, systemic illness, and local synthesis of cholesterol are thus excluded, the most reasonable explanation for the deposition of cholesterol in the eyes of children with a normal cholesteraemia would be the intermediary action of some tissue factor. This has been suggested by Reese, but his idea that the PAS-positive basement membrane demonstrated by him in the telangiectases is the tissue factor responsible for the later development of Coats's disease, is almost certainly incorrect, for a similar PAS-positive membrane occurs in the arterioles of detached retinae in eyes which show no early or late evidences of Coats's disease (see following communication). Similarly, it is almost impossible to believe that the massive lipid deposits in the lesions of Coats's disease could originate from degenerating neural elements in the retina or from extravasated erythrocytes. The most interesting hypothesis yet suggested is that offered by Faber to explain the deposition of lipids in the aorta-i.e. that this lipid deposition is mediated by a metachromatic material which always occurs in small amounts in the aortas of normal patients, but is present in greatly increased amounts in aortas in which there are deposits of cholesterol. This metachromatic material is an acid mucopolysaccharide, and is generally believed to be chondroitin acid sulphate. The application of this hypothesis to the pathogenesis of Coats's disease would lie in the positive identification of cholesterol as the chief lipid constituent deposited in the external retina and subretinal space, and the demonstration of such an acid mucopolysaccharide in the lesions of the disease.

Histochemical studies, undertaken to clear these points, will be reported in the next communication. The data here reported appear to justify the following conclusions.

\section{Conclusions}

(1) Coats's disease (Groups I and II, as described by him in 1908) is a clinical and histological entity. The clinical and histological pictures are the same in both the adult and the juvenile forms of the disease.

(2) The findings of the present study and a review of the literature give little support to the widely-held view that Coats's disease is usually unilateral and occurs predominantly in young males. 
(3) A review of the literature on Coats's disease indicates that the deposition of a lipid in the external retina has long been suspected to be a characteristic feature of Groups I and II, as originally described by Coats.

(4) While it has generally been assumed that cholesterol is the lipid involved, no actual proof for this assumption has been advanced.

(5) In the adult cases there is a definite hyperlipaemia, involving especially the cholesterol fraction, and also a history or physical evidence of some preceding uveal inflammation. The hypothesis is offered that, in the presence of a hypercholesteraemia, the insult from an inflammation in the uveal tract is the trigger mechanism which precedes and facilitates the local deposition of cholesterol in the retina. It is probable that the actual deposition of cholesterol is mediated through some tissue factor.

(6) In the juvenile cases the plasma lipids are consistently within normal limits, and there is usually no history of a preceding uveal inflammation or of any systemic disease to which the local deposition of cholesterol could be ascribed. It is probable, therefore, that the role of an as yet undemonstrated tissue factor which mediates the deposition of the cholesterol is a dominant one.

\section{REFERENCES}

Adlersberg, D., and Eisler, L. (1959). J. Amer. med. Ass., 170, 1261.

Alagna, G., and Di Perri, T. (1955). Arch. Ottal., 59, 103.

ANITSCHKow, N. (1913). Münch. med. Wschr., 60, 2555.

(1914). Beitr. Path. Anat., 57, 201.

Bauer, F. (1959). v. Graefes Arch. Ophthal., 161, 373.

Berengo, A., and FrezzotTI, R. (1962). Ophthalmologica (Basel), Suppl. 59, p. 265.

BERG, F. (1919). v. Graefes Arch. Ophthal., 98, 211.

BIETTI, G. (1936). Boll. Oculist., 15, 1.

Blodi, F. C. (1960). Trans. Amer. Acad. Ophthal. Otolaryng., 64, 720.

Bloor, W. R. (1915). J. biol. Chem., 23, 317.

BOYD, E. M. (1933). Ibid., 101, 323.

Bragdong, J. H., and Havel, R. J. (1954). Amer. J. Physiol., 177, 128.

CASTello, B. (1927). Ann. Ottal., 55, 607.

CoATs, G. (1908). Roy. Lond. ophthal. Hosp. Rep., 17, 440.

(1912). v. Graefes Arch. Ophthal., 81, 275.

Crigler, L. W. (1920). Arch. Ophthal. (N.Y.), 49, 287.

DuKE-ElDER, S. (1940). "Text-book of Ophthalmology", vol. 3, p. 2611. Kimpton, London.

DunPHY, E. B. (1950). Amer. J. Ophthal., 33, 1579.

ElWYN, H. (1946). "Diseases of the Retina", p. 148. Blakiston, Philadelphia.

FABER, M. (1946). Acta med. scand., 124, 545. (1949). Arch. Path. (Chicago), 48, 342.

Finley, J. K. (1961). Angiology, 12,127.

FraCASSI, L. (1956). G. ital. Oftal., 9, 235.

FrançoIs, J., RABAEY, M., Evens, L., and DE Vos, E. (1956). Ophthalmologica (Basel), $132,1$.

FrIedenWald, H. (1925). Arch. Ophthal. (N. Y.), 54, 111.

GIVNER, I. (1954). Amer. J. Ophthal., 38, 852.

GourfeIN-Welt, D. (1920). Klin. Mbl. Augenheilk., 65, 105.

HABEGGER, H. (1954). Arch. Ophtal., n. sér., 14, 470.

Hanssen, R. (1920). Klin. Mbl. Augenheilk., 65, 703.

Heath, P. (1932). Trans. Amer. Acad. Ophthal. Otolaryng., 37, 121.

HIPPEL, E. VON (1913). v. Graefes Arch. Ophthal., 86, 443.

IMRE, G. (1962). Amer. J. Ophthal., 54, 175.

JACOBS, L., Melton, M. L., Wood, R. M., and Woods, A. C. (1960). “Isolation of Toxoplasma from the Human Uvea and Retina" (unpublished). 
JunIus, P. (1934). Klin. Mbl. Augenheilk., 92, 748.

KLEIN, B. A. (1937). Amer. J. Ophthal., 20, 812.

KORN, E. D. (1955). J. biol. Chem., 215, 1.

LAMB, H. D. (1938). Amer. J. Ophthal., 21, 618.

LEBER, T. (1916). In “Graefe-Saemisch Handbuch", 2nd ed., bd 7, teil 2, kap. X A, part 2, p. 1267. Engelmann, Leipzig.

LEWIS, N. (1950). Brit.J. Ophthal., 34, 506. (1952). Ibid., 36, 325.

LINDAU, A. (1926). Acta path. scand., Suppl. 1.

MARShall, J., and Michaelson, I. C. (1933). Trans. ophthal. Soc. U.K., 53, 102.

Meller, J. (1922). Z. Augenheilk., 47, 247.

Michaelson, I. C. (1954). "Retinal Circulation in Man and Animals". Thomas, Springfield, Ill.

Mryashita, S., and NisYAKe, Y. (1921). Brit. J. Ophthal., 5, 448.

Mylius, C. (1935). Klin. Mbl. Augenheilk., 95, 257.

OguCHI, C., and MaJinIA, K. (1923). v. Graefes Arch. Ophthal., 111, 440.

RADOS, A. (1921). Ibid., 105, 973.

REese, A. B. (1956). Amer.J. Ophthal., $42,1$.

RIEGER, H. (1960). v. Graefes Arch. Ophthal., 162, 178.

SugAR, H. S. (1958). Amer. J. Ophthal., 45, 508.

ThanNHAUSER, S. J. (1958). "Lipidoses, Diseases of the Intracellular Lipid Metabolism", 3rd ed. Grune and Stratton, New York.

Thomas, P. K., and Smith, E. B. (1958). Brit. J. Ophthal., 42, 501.

Valvo, G. (1956). Arch. Ottal., 60, 199.

WiSE, G. N. (1957). A.M.A. Arch. Ophthal., 58, 735. (1961). Amer. J. Ophthal., 52, 637.

Wolter, J. R., Goldsmith, R. I., and Phillips, R. L. (1957). A.M.A. Arch. Ophthal., 57, 376.

Woods, A. C., and Stone, H. H. (1958). Amer. J. Ophthal., 45, 11.

Youngburg, G. E., and Youngburg, M. V. (1930). J. Lab. clin. Med., 16, 158. 